cance away from ridges and fracture zones was difficult to evaluate ${ }^{12}$.

Cannat et al. ${ }^{4}$ tested the hypothesis that some off-axis regions far from fracture zones represent thinned oceanic crust $^{5}$. In a study area bounded by the Kane Fracture Zone to the north and the Mid-Atlantic Ridge $\left(22-24^{\circ} \mathrm{N}\right)$ to the east, they dredged in both deep regions whose residual gravity signature suggested thin crust and shallow regions of inferred thick crust $^{5}$ (part $c$ of the figure). They found, however, that the deeper thin-crust regions have little, if any, basaltic component and consist largely of serpentinite emplaced to the surface directly by mantle upwelling, with minor gabbro and basalt. This is just what Harry Hess predicted ${ }^{3}$ in 1962. The gravity signatures suggest that such 'Hess crust' makes up 23 per cent of their study area, and is common in other areas of slowly spreading ridges as well ${ }^{13}$.

The new crustal model ${ }^{4,5}$ is directly related to the hypothesis of segmentation and focusing of magma generation in space and time $e^{8,9}$. Present-day generation of Hess crust occurs between main magmatic centres; lateral transport of magma in the crust is unable to cover the distal portions of the upwelling zones with a continuous blanket of basaltic rock. As magmatic centres wax, migrate along the ridge and wane ${ }^{8,9,14}$, the zones of Hess crust production also move back and forth along the ridge axis, producing ridgeoblique regions of peridotitic crust bounding distinctive rhombohedral zones of Penrose (layer-cake) crust.

The pure layer-cake structural model predicts basalt outcrop everywhere, except at fracture zones. It has become increasingly difficult to explain away nonfracture zone peridotites ${ }^{11,12,15}$ as tectonic slivers of lower crustal material emplaced into basaltic crust by some as yet mysterious mechanism. The widespread occurrence of Hess crust neatly solves this problem by incorporating peridotite outcrop into the overall structure of slowly spreading ridges. Another problem the new model solves is posed by tectonic lineations running oblique to the ridge axis. The Penrose (part $a$ of the figure) and pure focused accretion (part $b$ ) models provide no mechanism for the production of such structures. Exactly

1. Vine, F. J. \& Moores, E. M. Geol. Soc. Am. Mem. 132 195-208(1972)

2. Penrose Conference participants Geotimes 17, 24-25 (1972).

3. Hess, H. H. Geol. Soc. Am. Buddington Vol. 599-620 (1962).

4. Cannat, M., Mével, C. etal. Geology 23, 49-52 (1995)

5. Gente, P. et al. Earth planet. Sci. Lett. 129, 55-71 (1995).

6. Edmond, J. C. et al. Earth planet. Sci. Lett. 46, 1-18 (1979).

7. Staudigel, H. \& Hart, S. R. Geochim. cosmochim. Acta 47, 337-350 (1983).

8. Whitehead, J., Schouten, H. \& Dick, H. Nature 312 146-148(1984)

9. Lin, J. et al. Nature 344, 627-632 (1990). such structures divide regions of Penrose crust from Hess crust (part $c$ of the figure), and are probably caused by the growth, migration along ridge and death of magmatic accretion regions $\mathrm{s}^{4,5,11,14}$

This new model of the crustal structure of the ocean floor has substantial implications for the study of the Earth as a system. Most important is that serpentinized peridotite must be more common on the ocean floor than previously thought. Peridotite is much more reactive with sea water than is basalt, owing to their different mineralogy and chemical compositions. Basaltic crust is one of the main sinks for seawater magnesium ${ }^{6}$. Weathering peridotite, on the other hand, gives up large amounts of $\mathrm{Mg}$ to sea water ${ }^{16}$, and thus now forms an important source of $\mathrm{Mg}$ to the oceans. Similarly, peridotite accounts for nearly all of the other compatible elements (such as nickel, chromium and noble metals) present in the oceanic crust, and may account for addition of those elements to sea water as well. Serpentinized peridotite contains about 13 per cent water, bound in serpentine, talc and amphibole, about 10 times the amount in altered basalt. Thus, peridotite may account for much of the water bound in silicate crystal structures introduced into the mantle at subduction zones. Peridotite is also a known sink for alkali elements and boron ${ }^{17}$, so some part of the subduction budget of these elements may also be accounted for by peridotite.

Fast-spreading crust is still the most common type of ocean crust, in terms of current production, areal extent and volume subducted. But four major ocean basins are floored mostly by slowly spreading crust (the Arctic, North Atlantic, South Atlantic and Indian oceans) where serpentinite has now been shown to be an important constituent. Harry Hess never gave up his belief that serpentinite plays an essential role in oceanic crustal structure. Although layered basaltic crust remains the dominant ( $\sim 77$ per cent) crustal type on slow-spreading ridges, the incorporation of extensive serpentiniterich crust ${ }^{4}$ shows that he was at least partly right.

Jonathan $E$. Snow is in the Abteilung Geochemie of the Max-Planck-Institut für Chemie, 55020 Mainz, Germany.

10. Dick, H. J. B. in Magmatism in the Ocean Basins, Geol. Soc. Lond. spec. Publ. 42, 71-105 (1989).

11. Karson, J. A. et al Nature 328, 681-685 (1987).

12. Juteau, T., Cannat, M. \& Lagabrielle, G. Proc. Ocean Drilling Prog. B. 106/109 (College Station, Texas. 1988).

13. Phipps-Morgan, J. Earth planet. Sci. Lett. 129, 73-84 (1995).

14. Schouten, H., Dick, H. \& Klitgord, K. Nature 326 835-839 (1987)

15. Bougault, H. etal. J. geophys. Res. 98, 9643-9651 (1993).

16. Snow, J. \& Dick, H. Geochim. cosmochim. Acta (submitted).

17. Seyfried, W Janecky, D. \& Mottl, M. Geochim cosmochim. Acta 48, 557-569 (1984).

\section{Dental relaxation}

ManY vices, such as smoking, drinking and overeating, require you to put something in your mouth. Psychologists claim that this oral craving is a childhood desire emerging again in adult life. It certainly arouses childish guilt in the millions who yield to it.

The largest and guiltiest section of this vast group is that of the overeaters. Why does the overeater repeatedly feel that fatal craving to take another mouthful? Because, says Daedalus, the existing one has been chewed enough to become boring. The natural reaction is to swallow it and try again. So DREADCO's food technologists are now devising a chewing product whose taste, texture and oral interest will never become boring. It will change all the time, and retain its ora appeal almost indefinitely. At any stage it will seem wasteful and premature to swallow it.

Unlike chewing gum, with its few, rapidly exhausted, flavours, the new product will be loaded with a wide range of microcapsules of contrasting flavours, designed to degrade under chewing at different rates. As they do so, the taste will change slowly and subtly all the time. Similarly, its texture and viscosity must also keep on altering in the mouth. Many suspensions and polymer formulations change their viscosity dramatically and reversibly with water-absorption, temperature or rate of shear. Products from thixotropic paint to jelly explosive already exploit such properties. 'The Cud' (as DREADCO's ever-ingenious marketers have named the new product) will do likewise.

The Cud will transform the lives of the orally unsatisfied. Without being dramatically tasty, it will maintain a subtle oral interest for hours on end. Its flavour will drift slowly and unpredictably from savoury, through minty, fruity, cheesy and chocolatey to salty, and back again. Its texture will be crisp, chewy, soft and stringy by turns, as its particles clump together or break down and as the user's saliva slowly penetrates the hydrophilic components of its structure. It will be almost permanently satisfying. The contented chewer will never have that fatal desire to take another mouthful.

Television-addicted couch potatoes, bored office workers, housewives in food-laden kitchens, all will find a calm, bovine satisfaction in chewing The Cud. With their primitive oral needs so deeply satisfied, they will no longer be tempted to overeat, and maybe not to drink or smoke either. A vast amount of health self-sabotage will be avoided. Only the snack and beverage industries will suffer.

David Jones 